\title{
The spaces in between
}

\author{
Cite as: CMAJ 2017 June 19;189:E838-9. doi: 10.1503/cmaj.161159
}

was going to walk into the room of a patient I had never met to tell him his cancer had progressed. He was young and had children in college. He was still getting radiation and had completed a course of chemotherapy. Today, he was admitted by his radiation oncologist because his abdominal pain was so severe that they could not even complete the session. He actually looked well, apart from the abdominal distension, and he was smiling when I entered. I asked the perfunctory questions and we talked for a bit. I gently tried to ask if his family would be coming in today.

After discussing how we could control his pain, I reviewed the computed tomography results with him. The abdominal mass was now almost $20 \mathrm{~cm}$, and there were more metastases. He asked "How can I say goodbye to my children?" I said "I don't know" and then there was silence.

When I was a student and resident, I understood concepts of empathy. I knew the phrases to say and the body language. I knew to listen to the patients talk for a few minutes before I dove in with my burning questions. I did not know the importance of silence. I should have. I was going to go into music before I opted for the stability of medicine. I had been taught by musicians greater than myself that it is the silence, not the notes, that creates beauty in a piece of music. There are many people who can learn to play the notes if they are willing to devote the hours of practice needed. The notes, however expressively they are caressed, pale in comparison with the silence. Those microseconds of emptiness distinguish the artists from the novices. It is what packs a concert hall. That precious emptiness creates the music we love, even if we do not routinely value it as much as the notes.

Medicine is not very comfortable with silence. Our electronic medical record is noisy. Our hospitals are constantly abuzz at all hours of the day and night. When we

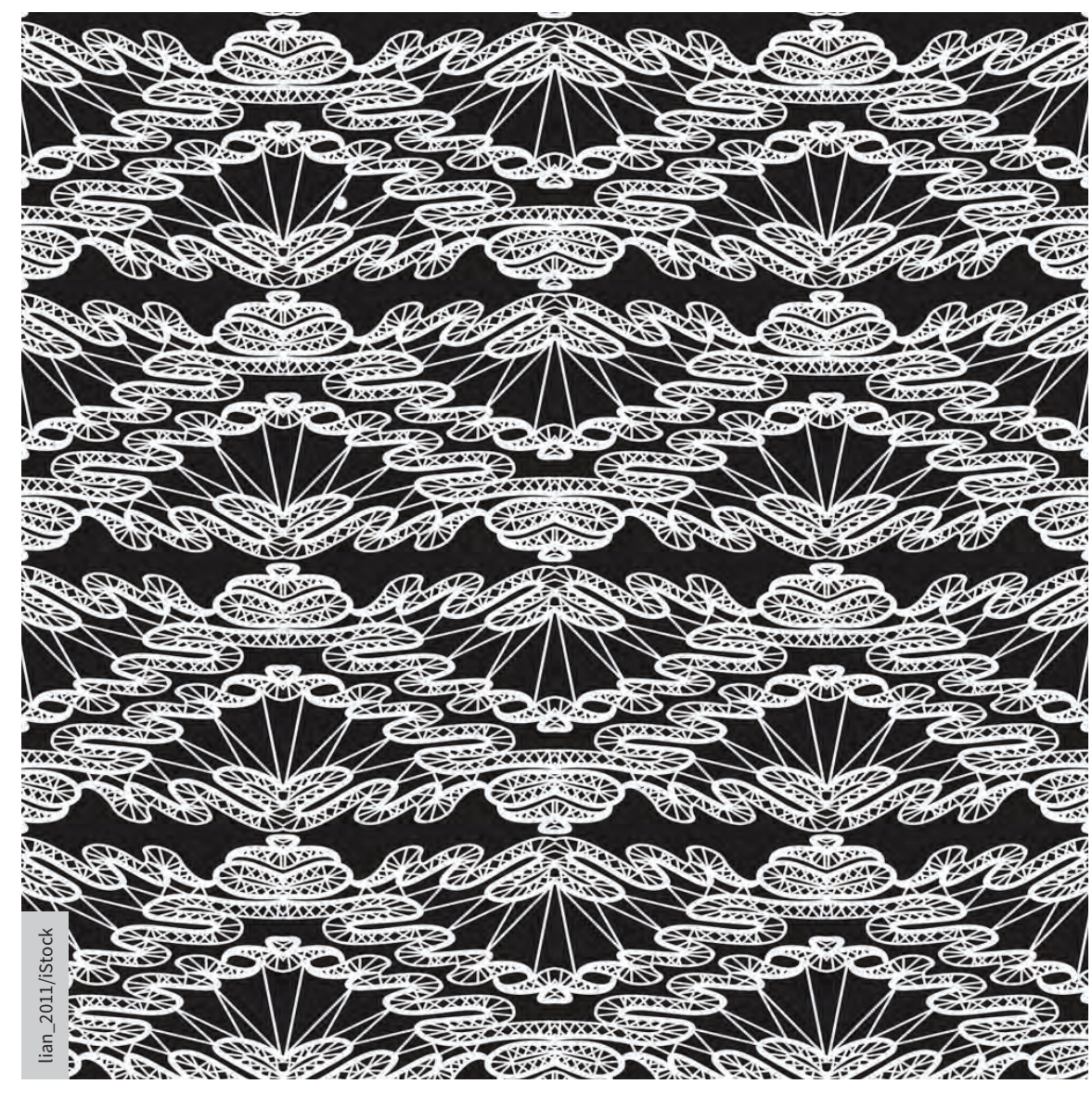

round with our large teams of students and residents, we recreate our patients' life experiences in 10 minutes. We talk at our patients, reviewing, explaining, discussing options. Nurses page my intern away from the bedside during sensitive moments of an encounter. Our ubiquitous electronic devices lay waiting close at hand to fill a moment of reflection. Words, documentation and communication are the currency of medicine in the hospital, but the luxury of silence has largely escaped us as a field.

As a younger physician, silence can seem to be a dangerous thing. Patients would think we did not have all the answers, that we were unsure of what to do next, or worst of all, that we were incompetent. Even platitudes could seem preferable to the void left by our voice staying in our head, although these banal platitudes may in fact be more dangerous than quiet, a philosophy held by Nietzsche and Nietzsche's beloved Montaigne. Filling the space with sounds and thoughts bolsters a young physician's perception of the visit, but does it create the space our patients need? When they are suffering for any reason, mental or physical, does reaching into our doctor's bag for words always alleviate the pain?

Children understand the importance of just being present. I did not truly appreciate this until I had children, when I realized that they really do not need you to talk all the time. They just want you there while they play their game or read their 
book. They do not need words. This father who was dying of cancer knew far too well what to expect, and he did not need words, so we sat for a while. He asked a few questions here and there, and cried intermittently. We did talk more after that, and I came back when his wife and his mother arrived.

His pain was eventually controlled. We did a paracentesis that relieved some of his symptoms and had consulted palliative care for his pain and for outpatient follow-up. He was going to see his oncologist the next week and discuss secondand third-line chemotherapy options. And then I discharged him.

As a hospitalist, I often do not get to see my patients again apart from a call a few days after they are home. But my patient returned a couple of months later, looking much frailer, thinner, paler and with graying hair. He had a small bowel obstruction. Our surgeons recognized a surgery would not go well for him, so we waited. The typically musical bowel sounds were absent. There was also silence in his bowels, as they were encased with cancer. We waited days and then over a week. The various bowel regimens did nothing. He and his family did not want to start total paren- teral nutrition after we discussed it. He declined a vented gastrostomy tube. $\mathrm{He}$ did not like the mental slowing induced by the narcotics.

I went in every day and sometimes just spoke with him, sometimes his mother, father or wife was there. We talked about his spiritual beliefs, his children, his disease, but we were quiet sometimes, recognizing the limitations of our language to express the transition he was going through right now. He was ready to go home on hospice care and ready to say goodbye. His family was supportive and warm. I never met his children, although I imagined what he said and what I would say to my children.

Our words and our silences are as much a treatment tool as any medicine or surgery and, as with any treatment, must be used thoughtfully and properly to affect healing. The absence of speech does not create true silence. Artful, effective silence is defined by patience and receptivity. It is cultivated by our sensitivity to our patients' needs at that moment and an abrogation of our needs. It is a state of mindful attentiveness and not a hollow opening devoid of meaning. It is not that lull we wait for in a conversation so we can jump in. It is a moment of creation and understanding. In music, we can appreciate these moments of silence, however fleeting they may be.

One of the most powerful aspects of music is that very ephemeral nature, because it exists for a brief moment and dies away. As soon as a note is struck, it begins to die away, and thus the concept of silence becomes that much more nuanced. Therefore, silence is not an absolute absence of sound but rather a relative quiet. The silence after the music, the space created between notes and words are the holes that create the lace.

Silence does not come naturally to us, but the incessant and systemic cacophony of our lives must be quieted at times. Music expresses some of what words cannot and so does silence.

\section{Elizabeth Cerceo MD}

Assistant Professor, Division of Hospital Medicine, and Associate Program Director of the Internal Medicine Residency, Cooper Medical School of Rowan University, Camden, NJ

This is a true story. The patient's spouse has given consent for this story to be told. 